\title{
A Literature Review on the Auditor's Independence Between Threats and Safeguards
}

\author{
Andreea Claudia CRUCEAN, PhD student \\ West University of Timişoara, Romania
}

\begin{abstract}
The paper aims to identify the threats to the auditor's independence and to discuss this subject from a theoretically point of view. Auditor independence is one of the seven principles of professional ethics, necessary to perform a fair and professional audit engagement. In this paper, I have reviewed the literature and analyzed some of the most relevant scientific articles that have researched this topic. For the case study, I chose to analyze the most relevant papers in this area taking into account the objective pursued by the author, the research methodology, the selected sample, the variables and the category of threats to auditor independence. Subsequently, were split the discovered threats into groups and identified a series of safeguards to limit the threats to the auditor's independence. The main conclusion is that an in-depth knowledge, the exercise of the procedures for mitigating the effects of threats to the auditor's independence and compliance with professional and ethical rules are factors that ensure the successful performance of an audit process.
\end{abstract}

Key terms: auditor independence, ethics, threats, safeguards

JEL Classification: M40, M42

To cite this article: Andreea Claudia Crucean, A Literature Review on the Auditor's Independence Between Threats and Safeguards, CECCAR Business Review, № 7/2020, pp. 64-72, DOI: http://dx.doi.org/10.37945/cbr.2020.07.08

\section{Introduction}

Auditor independence is a cornerstone of the audit profession, a crucial element in the legal process of financial reporting that contributes to increasing the added value of the audited financial statements.

However, the financial crises and the corporate collapses at the beginning of the 21st century have caused many changes to the audit process and, indirectly, even to the auditor's independence. Especially, the economic dependence resulting from the provision of non-audit services by audit firms, the familiarity resulting from the auditor's experience and personal relationships built through employees were considered factors that led to the erosion of auditor independence.

An external auditor faces many threats that could affect his independence. If his independence is impaired, he becomes unable to issue a correct report that indicates the accuracy of the audited financial statements in accordance with the requirements of international audit standards. The auditor's career can be affected and the future acceptance by another client will be lowered, thus reducing the users' confidence in the services provided by the auditor.

The objective of the article is to identify the most important information and concepts in the case of auditor independence and the practical implications based on literature and the Code of ethics for professional auditors. 


\section{Theoretical considerations}

In order to highlight the current state of knowledge in the chosen subject area, the most important concepts, elements and factors that influence the research topic will be presented.

In recent years, especially following the great financial scandals (in which the role of auditors has not always been neutral), there has been an increase of concerns for the study of factors that influence audit quality, one of these factors being the auditor's independence.

Starting from DeAngelo's (1981) definition that defines audit quality as a double probability through which the auditor can detect significant misstatements, the main factors that can be identified as influencing audit quality are: the auditor's ability to identify misstatements, the procedures used and the sample size, all of which depend significantly on the auditor's competence and endowment with appropriate technologies. This definition also refers to the auditor's competence and independence, two important characteristics, especially when they are discovered as the causes of fraud or accounting errors. The lack of effort or competence prevents an auditor from detecting problems that need to be resolved, and the lack of independence prevents an auditor from correcting the problems identified in the client's pre-audit financial statements.

The Code of ethics for professional auditors defines independence as a state of mind that allows the auditor to issue an opinion without being affected by influences that could compromise his professional judgment, to act with integrity and to exercise objectivity and professional skepticism.

According to the authors Pittman et al. (2020), the characteristics of the individual auditor play an important role in audit quality. Assessing the implications of audit quality on the risk tolerance of partners is a common test used to determine their risk profiles that affect their performance and manifest in the audit results.

Al-Nawaiseh and Alnawaiseh (2015) are of the opinion that independence refers to the fact that an auditor must express his opinion about the financial statements without being influenced by any threat from any source, but also to an auditor's ability to avoid the influence of any threat from any source.

Ghosh et al. (2016) consider that an auditor's independence is also reflected in the duty to obtain sufficient appropriate audit evidence on which to base his opinion.

Tahir et al. (2014) have developed a model in which an auditor decides on an optimal model on the level of independence applicable on the bond market. This decision is influenced by the level of fees charged to diminish the independence of the costs that arise when the quality of the reports is poorly monitored or fraud detection is less efficient. Capital costs are inversely proportional to the auditor's independence.

Auditor independence affects the capital costs in two ways. Firstly, a greater independence leads to better monitoring of the firm's net assets by external auditors and to higher fraud detection rates. Better monitoring by auditors allows investors to opt out of their expensive monitoring activities aimed at reducing the risk of expropriation by managers.

Mohamed and Habib (2013) have studied the issue of the auditor's lack of independence in the Egyptian context and how this topic affects audit quality based on a questionnaire distributed among the audit practitioners within the Big Four audit companies operating in Egypt. The main reason for the lack of independence is the weak structure of closely held corporations. It has also been found that the voluntary switching of auditors aims to improve quality, suggesting that the rotation of auditors as an optimal solution.

Cordoș and Fulop (2013) consider that the auditor's rotation is not necessary to increase audit quality, because a specialist's knowledge of a client is proportional to the duration of the period in which he is an auditor. In addition to this, imposing the obligation to change the auditor would restrict the investor's freedom to choose an auditor according to their needs and those of the company. 


\section{Research methodology}

The research method is a qualitative one, taking into account that the article aims to be more of a theoretical documentation, respectively a descriptive-explanatory study of the most relevant scientific articles. For this purpose, I have analyzed and synthesized the information identified in the mentioned articles in Table 1.

To highlight this aspect, I have summarized the information obtained after analyzing the articles included in the sample in Table 1. The articles were selected mostly from international business administration databases, in order to identify research at international level, but also from Romanian publications. The chosen period is 2006-2019 and the selection criterion was the existence of the words "audit", "independence", or the phrase "auditor independence". An initial number of 47 articles were obtained, out of which the 15 most representative ones were selected.

\section{Results}

I analyzed the objective of each article, the main results, the chosen sample, the research methodology and whether there were any independent or dependent variables in the case of a quantitative methods. The most significant results are presented in the first table.

Table 1. Studies on the threats to the auditor's independence

\begin{tabular}{|c|c|c|c|c|c|c|}
\hline $\begin{array}{l}\text { Author/s } \\
\text { and year }\end{array}$ & Objective & Results & Sample & $\begin{array}{c}\text { Research } \\
\text { methodology }\end{array}$ & Variables & $\begin{array}{l}\text { Threat } \\
\text { category }\end{array}$ \\
\hline $\begin{array}{l}\text { Yustina and } \\
\text { Gonadi } \\
\text { (2019) }\end{array}$ & $\begin{array}{l}\text { Examine whether } \\
\text { time pressure } \\
\text { affects professional } \\
\text { skepticism and } \\
\text { whether the effect is } \\
\text { mediated by the } \\
\text { auditor's } \\
\text { independence. }\end{array}$ & $\begin{array}{l}\text { Auditor } \\
\text { independence } \\
\text { mediates the } \\
\text { relationship } \\
\text { between the } \\
\text { variables. } \\
\text { It is recommended } \\
\text { to increase the } \\
\text { number of } \\
\text { members of the } \\
\text { audit team and the } \\
\text { presence of a } \\
\text { supervisor. }\end{array}$ & $\begin{array}{l}163 \text { external } \\
\text { auditors from } \\
\text { Jakarta (Big Four) }\end{array}$ & $\begin{array}{l}\text { Survey } \\
\text { Empirical } \\
\text { model based } \\
\text { on two } \\
\text { hypotheses }\end{array}$ & $\begin{array}{l}\text { Independent: } \\
\text { time pressure } \\
\text { Dependent: } \\
\text { professional } \\
\text { skepticism }\end{array}$ & Intimidation \\
\hline $\begin{array}{l}\text { Tănase and } \\
\text { Ştefănescu } \\
\text { (2020) }\end{array}$ & $\begin{array}{l}\text { Tracking rotation } \\
\text { practices within } \\
\text { banking institutions } \\
\text { in Romania. }\end{array}$ & $\begin{array}{l}\text { Most banks have } \\
\text { adopted their own } \\
\text { rotation policy for } \\
\text { partners or audit } \\
\text { firms. }\end{array}$ & $\begin{array}{l}29 \text { banks on the } \\
\text { Romanian market }\end{array}$ & $\begin{array}{l}\text { Qualitative } \\
\text { study }\end{array}$ & $\begin{array}{l}\text { Not } \\
\text { necessary }\end{array}$ & Familiarity \\
\hline $\begin{array}{l}\text { Chang et al. } \\
\text { (2019) }\end{array}$ & $\begin{array}{l}\text { Examine whether } \\
\text { audit partners can } \\
\text { compromise their } \\
\text { independence for } \\
\text { economically } \\
\text { important clients of } \\
\text { affiliated business } \\
\text { groups. }\end{array}$ & $\begin{array}{l}\text { Audit partners are } \\
\text { more likely to } \\
\text { compromise their } \\
\text { independence for } \\
\text { economically } \\
\text { important clients. } \\
\text { The independence } \\
\text { of audit partners in } \\
\text { the Big Four is more } \\
\text { significant than that } \\
\text { of the non-Big Four } \\
\text { audit partners. }\end{array}$ & $\begin{array}{l}\text { Clients of audit } \\
\text { partners }\end{array}$ & $\begin{array}{l}\text { Empirical } \\
\text { model based } \\
\text { on three } \\
\text { hypotheses }\end{array}$ & $\begin{array}{l}\text { Independent: } \\
\text { total assets } \\
\text { Dependent: } \\
\text { earnings and } \\
\text { cash flow }\end{array}$ & Self-interest \\
\hline
\end{tabular}




\begin{tabular}{|c|c|c|c|c|c|c|}
\hline $\begin{array}{l}\text { Author/s } \\
\text { and year }\end{array}$ & Objective & Results & Sample & $\begin{array}{c}\text { Research } \\
\text { methodology }\end{array}$ & Variables & $\begin{array}{l}\text { Threat } \\
\text { category }\end{array}$ \\
\hline $\begin{array}{l}\text { Honigsberg } \\
\text { (2019) }\end{array}$ & $\begin{array}{l}\text { Investigates whether } \\
\text { an audit company's } \\
\text { reputation } \\
\text { influences the } \\
\text { accountants and } \\
\text { determines optimal } \\
\text { levels of attitudes } \\
\text { regarding the audit } \\
\text { of the company. }\end{array}$ & $\begin{array}{l}\text { Marketing of } \\
\text { individual auditors } \\
\text { could increase } \\
\text { industry } \\
\text { competition } \\
\text { without the need } \\
\text { for aggressive rules. }\end{array}$ & $\begin{array}{l}\text { PCAOB inspections } \\
\text { issued for the } \\
\text { period 2005-2016 }\end{array}$ & $\begin{array}{l}\text { Qualitative } \\
\text { study }\end{array}$ & $\begin{array}{l}\text { Not } \\
\text { necessary }\end{array}$ & Advocacy \\
\hline $\begin{array}{l}\text { Sori and } \\
\text { Karbhari } \\
(2017)\end{array}$ & $\begin{array}{l}\text { Investigate the } \\
\text { impact of the } \\
\text { auditor's reputation } \\
\text { on the auditor's } \\
\text { independence. }\end{array}$ & $\begin{array}{l}\text { Most of the } \\
\text { auditors, loan } \\
\text { officers and } \\
\text { superior managers } \\
\text { of listed companies } \\
\text { agreed that } \\
\text { auditors in the } \\
\text { Big Four companies } \\
\text { are superior to their } \\
\text { counterparts in } \\
\text { non-Big Four } \\
\text { companies in all the } \\
\text { reputational issues } \\
\text { presented to them. }\end{array}$ & $\begin{array}{l}\text { Mangers of audit } \\
\text { companies, banks } \\
\text { and listed } \\
\text { companies }\end{array}$ & Survey & $\begin{array}{l}\text { Not } \\
\text { necessary }\end{array}$ & Self-review \\
\hline $\begin{array}{l}\text { Azibi et al. } \\
\text { (2017) }\end{array}$ & $\begin{array}{l}\text { Studied whether } \\
\text { the auditor's } \\
\text { independence } \\
\text { increases as a result } \\
\text { of the regulation } \\
\text { of the } \mathrm{H} 3 \mathrm{C} \text { act. } \\
\text { (The regulation of } \\
\text { the audit profession } \\
\text { in France.) }\end{array}$ & $\begin{array}{l}\text { Independence } \\
\text { increased after the } \\
\text { establishment of } \\
\text { H3C. Contrary to } \\
\text { this result, the } \\
\text { independence of } \\
\text { auditors did not } \\
\text { change significantly } \\
\text { after the inspection } \\
\text { process was } \\
\text { announced. }\end{array}$ & $\begin{array}{l}140 \text { companies } \\
\text { included in } \\
\text { international } \\
\text { databases }\end{array}$ & $\begin{array}{l}\text { Empirical } \\
\text { model }\end{array}$ & $\begin{array}{l}\text { Independent: } \\
\text { auditor } \\
\text { independence } \\
\text { Dependent: } \\
\text { audit fees } \\
\text { and total } \\
\text { assets }\end{array}$ & Advocacy \\
\hline $\begin{array}{l}\text { Huiying and } \\
\text { Ying (2016) }\end{array}$ & $\begin{array}{l}\text { Offering prospects } \\
\text { for achieving auditor } \\
\text { independence in the } \\
\text { economic and } \\
\text { cultural policy field }\end{array}$ & $\begin{array}{l}\text { Auditors who work } \\
\text { under pressure } \\
\text { tend to reduce } \\
\text { audit fees, avoid } \\
\text { issuing qualified } \\
\text { opinions, and offer } \\
\text { additional advice } \\
\text { and assistance on } \\
\text { financial reporting. }\end{array}$ & $\begin{array}{l}\text { Seven managers, } \\
\text { five independent } \\
\text { chairmen, five } \\
\text { auditors and four } \\
\text { academics }\end{array}$ & $\begin{array}{l}\text { E-mail } \\
\text { or phone } \\
\text { interview }\end{array}$ & $\begin{array}{l}\text { Not } \\
\text { necessary }\end{array}$ & Self-interest \\
\hline $\begin{array}{l}\text { Junaidi et al. } \\
\text { (2016) }\end{array}$ & $\begin{array}{l}\text { Empirical testing } \\
\text { of the effects of } \\
\text { auditor rotation } \\
\text { on auditor } \\
\text { independence }\end{array}$ & $\begin{array}{l}\text { The long tenure of } \\
\text { an auditor can have } \\
\text { negative effects } \\
\text { on the auditor } \\
\text { independence. } \\
\text { The rotation of the } \\
\text { auditors has a } \\
\text { significant influence } \\
\text { effects on auditor } \\
\text { independence. }\end{array}$ & $\begin{array}{l}\text { Listed companies } \\
\text { from Indonesia } \\
\text { in the period } \\
2002-2010\end{array}$ & Regression & $\begin{array}{l}\text { Independent: } \\
\text { auditor } \\
\text { independence } \\
\text { Dependent: } \\
\text { auditor } \\
\text { rotation and } \\
\text { reputation }\end{array}$ & Self-review \\
\hline
\end{tabular}




\begin{tabular}{|c|c|c|c|c|c|c|}
\hline $\begin{array}{l}\text { Author/s } \\
\text { and year }\end{array}$ & Objective & Results & Sample & $\begin{array}{c}\text { Research } \\
\text { methodology }\end{array}$ & Variables & $\begin{array}{l}\text { Threat } \\
\text { category }\end{array}$ \\
\hline $\begin{array}{l}\text { Ahmed } \\
\text { (2015) }\end{array}$ & $\begin{array}{l}\text { Examines whether } \\
\text { the practice of hiring } \\
\text { ex-auditors affects } \\
\text { the perspective of } \\
\text { financial statements } \\
\text { users on auditor } \\
\text { independence. }\end{array}$ & $\begin{array}{l}\text { A cooling period } \\
\text { of two years could } \\
\text { reduce the negative } \\
\text { impact on } \\
\text { independence from } \\
\text { the practices of } \\
\text { previous auditors. }\end{array}$ & $\begin{array}{l}\text { Corporate and loan } \\
\text { officers and } \\
\text { professional } \\
\text { investors from } \\
\text { Malaysia }\end{array}$ & Survey & $\begin{array}{l}\text { Not } \\
\text { necessary }\end{array}$ & Self-review \\
\hline $\begin{array}{l}\text { Austin and } \\
\text { Herath } \\
(2014)\end{array}$ & $\begin{array}{l}\text { Research the } \\
\text { specialized literature } \\
\text { on auditor } \\
\text { independence }\end{array}$ & $\begin{array}{l}\text { A wide range of } \\
\text { areas has been } \\
\text { discussed and these } \\
\text { issues can be } \\
\text { incorporated into } \\
\text { the revision of } \\
\text { curricula related } \\
\text { to auditor } \\
\text { independence. }\end{array}$ & $\begin{array}{l}\text { Research papers } \\
\text { published } \\
\text { in 1992-2010 }\end{array}$ & Survey & $\begin{array}{l}\text { Not } \\
\text { necessary }\end{array}$ & Advocacy \\
\hline $\begin{array}{l}\text { Kamau et al. } \\
\text { (2014) }\end{array}$ & $\begin{array}{l}\text { Established the } \\
\text { independence } \\
\text { status of internal } \\
\text { auditors }\end{array}$ & $\begin{array}{l}\text { The involvement } \\
\text { level of internal } \\
\text { auditors in } \\
\text { management } \\
\text { activities affects } \\
\text { their professional } \\
\text { independence } \\
\text { significantly. }\end{array}$ & $\begin{array}{l}\text { Social media } \\
\text { groups for } \\
\text { accountants and } \\
\text { auditors (Kenya) }\end{array}$ & $\begin{array}{l}\text { Empirical } \\
\text { model based } \\
\text { on four } \\
\text { hypotheses }\end{array}$ & $\begin{array}{l}\text { Independent: } \\
\text { internal } \\
\text { auditor } \\
\text { implication } \\
\text { Dependent: } \\
\text { auditor } \\
\text { independence }\end{array}$ & Self-interest \\
\hline $\begin{array}{l}\text { Cordoş and } \\
\text { Fulop (2013) }\end{array}$ & $\begin{array}{l}\text { Study how the } \\
\text { duration of the } \\
\text { auditor-client } \\
\text { relationship affects } \\
\text { the auditor's } \\
\text { independence. }\end{array}$ & $\begin{array}{l}\text { The sampled } \\
\text { companies tend to } \\
\text { choose a Big Four } \\
\text { auditor as their } \\
\text { audit partner. }\end{array}$ & $\begin{array}{l}25 \text { companies listed } \\
\text { on the London } \\
\text { Stock Exchange and } \\
\text { companies listed } \\
\text { on the Bucharest } \\
\text { Stock Exchange in } \\
\text { the 1st category }\end{array}$ & $\begin{array}{l}\text { A deductive } \\
\text { approach } \\
\text { from general } \\
\text { to private } \\
\text { which } \\
\text { combines } \\
\text { quantitative } \\
\text { and } \\
\text { qualitative } \\
\text { studies }\end{array}$ & $\begin{array}{l}\text { Not } \\
\text { necessary }\end{array}$ & Familiarity \\
\hline $\begin{array}{l}\text { Dogui et al. } \\
\text { (2013) }\end{array}$ & $\begin{array}{l}\text { The way in which } \\
\text { auditor } \\
\text { independence is } \\
\text { built within the } \\
\text { network of persons } \\
\text { involved in the } \\
\text { fulfillment of the } \\
\text { ISO } 14001 \text { audit } \\
\text { commitments }\end{array}$ & $\begin{array}{l}\text { Practitioners use a } \\
\text { range of strategies } \\
\text { to build and } \\
\text { maintain the belief } \\
\text { that ISO } 14001 \\
\text { audits meet the } \\
\text { professional } \\
\text { requirements } \\
\text { of auditor } \\
\text { independence. }\end{array}$ & $\begin{array}{l}\text { Canadian } \\
\text { practitioners, } \\
\text { including ISO } \\
\text { auditors, } \\
\text { certification body } \\
\text { managers, } \\
\text { accreditation } \\
\text { inspectors, } \\
\text { consultants and } \\
\text { managers }\end{array}$ & $\begin{array}{l}\text { Descriptive- } \\
\text { explanatory } \\
\text { study }\end{array}$ & $\begin{array}{l}\text { Not } \\
\text { necessary }\end{array}$ & Familiarity \\
\hline $\begin{array}{l}\text { Suseno } \\
(2013)\end{array}$ & $\begin{array}{l}\text { Investigate the } \\
\text { influence of auditor } \\
\text { independence and } \\
\text { audit fees on audit } \\
\text { quality }\end{array}$ & $\begin{array}{l}\text { Auditor } \\
\text { independence } \\
\text { significantly } \\
\text { influenced audit } \\
\text { quality and audit } \\
\text { fees, thus changing } \\
\text { the quality of the } \\
\text { audit. }\end{array}$ & $\begin{array}{l}73 \text { public } \\
\text { accounting offices } \\
\text { from the capital } \\
\text { market of } \\
\text { Indonesia }\end{array}$ & Interview & $\begin{array}{l}\text { Independent: } \\
\text { auditor } \\
\text { independence } \\
\text { Dependent: } \\
\text { audit team } \\
\text { size, risks }\end{array}$ & Intimidation \\
\hline
\end{tabular}




\begin{tabular}{|c|c|c|c|c|c|c|}
\hline $\begin{array}{l}\text { Author/s } \\
\text { and year }\end{array}$ & Objective & Results & Sample & $\begin{array}{c}\text { Research } \\
\text { methodology }\end{array}$ & Variables & $\begin{array}{l}\text { Threat } \\
\text { category }\end{array}$ \\
\hline $\begin{array}{l}\text { Gul et al. } \\
\text { (2007) }\end{array}$ & $\begin{array}{l}\text { Examines the impact } \\
\text { of non-audit fees } \\
\text { on auditor } \\
\text { independence. }\end{array}$ & $\begin{array}{l}\text { The association } \\
\text { between non-audit } \\
\text { fees and auditor } \\
\text { independence is } \\
\text { conditioned by the } \\
\text { auditor's tenure } \\
\text { and has an impact } \\
\text { on auditor } \\
\text { independence } \\
\text { when the audit } \\
\text { duration is short } \\
\text { and the client's size } \\
\text { is small. }\end{array}$ & $\begin{array}{l}4,720 \text { USA } \\
\text { companies from } \\
\text { the period } \\
2000-2001\end{array}$ & $\begin{array}{l}\text { Empirical } \\
\text { model }\end{array}$ & $\begin{array}{l}\text { Independent: } \\
\text { audit fees } \\
\text { Dependent: } \\
\text { ROA, total } \\
\text { assets }\end{array}$ & Self-review \\
\hline $\begin{array}{l}\text { Alleyne et al. } \\
\text { (2006) }\end{array}$ & $\begin{array}{l}\text { Investigate the } \\
\text { perceptions of users } \\
\text { from Barbados } \\
\text { on auditor } \\
\text { independence. }\end{array}$ & $\begin{array}{l}\text { Auditor's economic } \\
\text { dependence in } \\
\text { relation with the } \\
\text { client, the high } \\
\text { competition, a long } \\
\text { period of time and } \\
\text { the size of the audit } \\
\text { firm negatively } \\
\text { affected the } \\
\text { auditor's } \\
\text { independence. }\end{array}$ & $\begin{array}{l}66 \text { auditors and } \\
148 \text { users }\end{array}$ & Survey & $\begin{array}{l}\text { Not } \\
\text { necessary }\end{array}$ & Familiarity \\
\hline
\end{tabular}

Source: Own projection.

One may notice the repetitiveness of some factors that can threaten the auditor's independence, such as: legal rules in this area (three cases), followed by auditor rotation and reputation, the relationship between auditors and clients, and also the audit fees. Less frequent factors are time pressure, professional skepticism, and other aspect from literature.

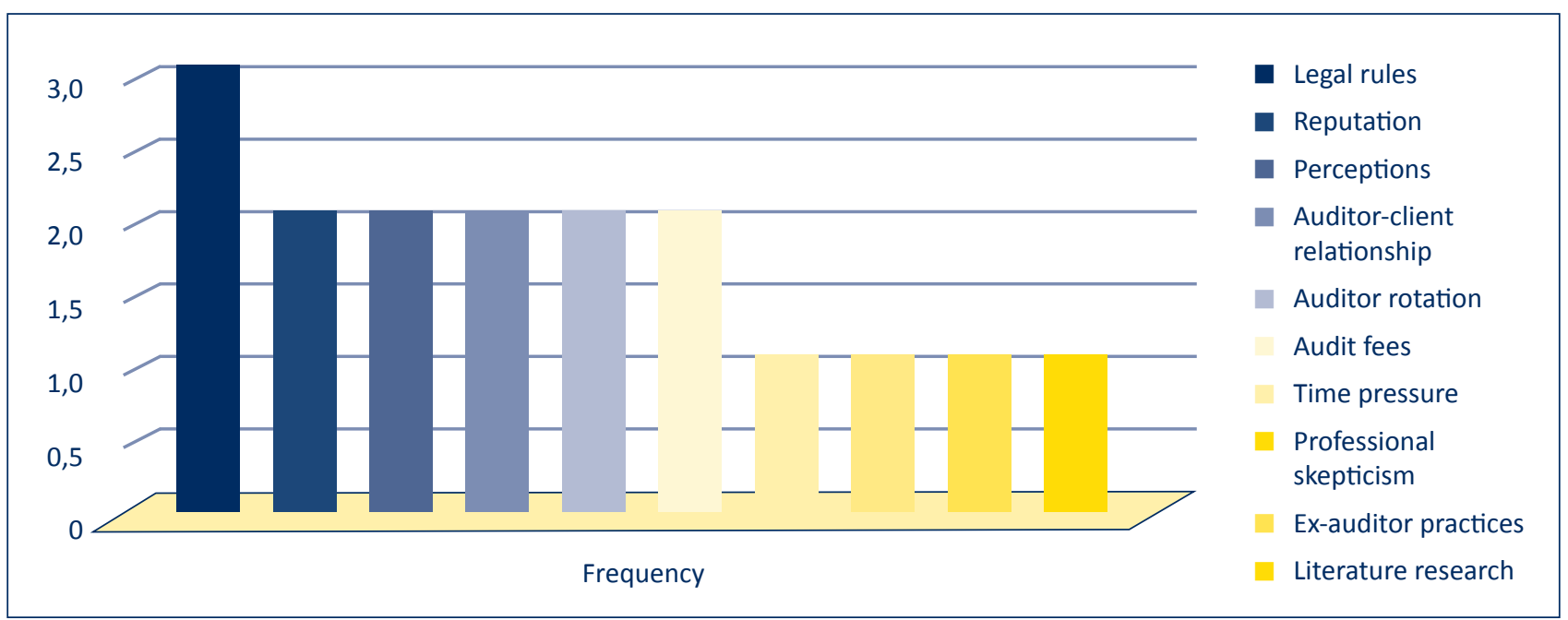

Figure 1. Threats frequency

Source: Own projection. 
The main research methods used by the authors focused on the quantitative empirical model (based on several hypotheses), followed by qualitative studies such as explanatory studies (27\%), surveys (27\%) and phone or email interviews (13\%).

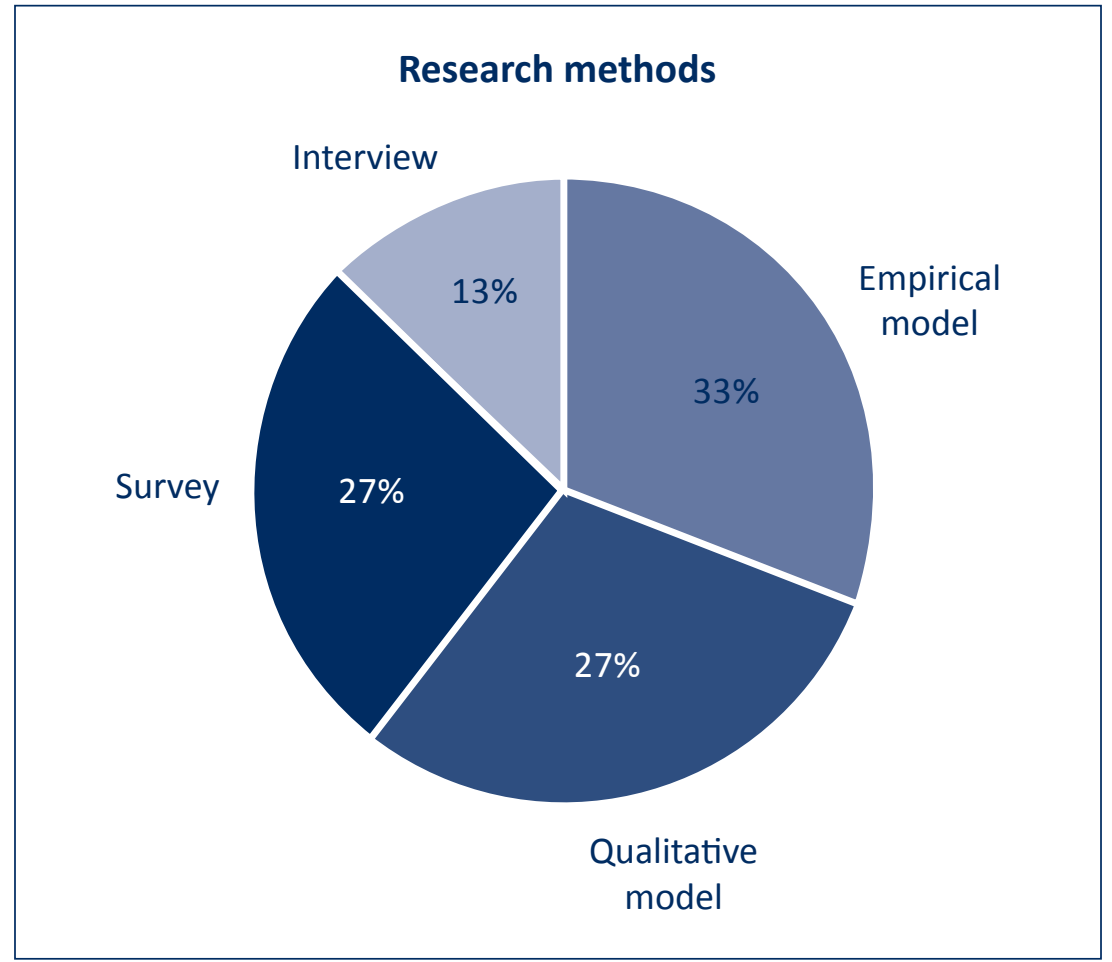

Figure 2. Research methods used by the authors

Source: Own projection.

I have identified the drivers for each category of threat to the auditor's independence and proposed a few safeguards that can prevent their influence on auditor independence, based on articles which studied the effects of these drivers.

Table 2. Threats to auditor independence and safeguards

\begin{tabular}{|c|c|c|c|c|c|}
\hline Category & Self-interest & Self-review & Advocacy & Familiarity & Intimidation \\
\hline Factors & $\begin{array}{l}\text { - Dependence } \\
\text { on fees } \\
\text { - Financial } \\
\text { interests } \\
\text { - Loans or } \\
\text { guarantees from } \\
\text { the client }\end{array}$ & $\begin{array}{l}\text { - Contribution to } \\
\text { the preparation } \\
\text { of financial } \\
\text { statements } \\
\text { - A close } \\
\text { business } \\
\text { relationship with } \\
\text { the client } \\
\text { - Previously } \\
\text { performed audit } \\
\text { tasks }\end{array}$ & $\begin{array}{l}\text { - Legal } \\
\text { requirements }\end{array}$ & $\begin{array}{l}\text { - Habit } \\
\text { - Nepotism } \\
\text { - Favoritism }\end{array}$ & $\begin{array}{l}\text { - Audit fees } \\
\text { - Pressure }\end{array}$ \\
\hline
\end{tabular}




\begin{tabular}{|c|c|c|c|c|c|}
\hline Category & Self-interest & Self-review & Advocacy & Familiarity & Intimidation \\
\hline Safeguards & $\begin{array}{l}\text { - Continuous } \\
\text { professional } \\
\text { training } \\
\text { - Professional } \\
\text { certification } \\
\text { and experience } \\
\text { requirements to } \\
\text { gain access to } \\
\text { the profession } \\
\text { - Monitoring } \\
\text { the activity } \\
\text { and applying } \\
\text { disciplinary } \\
\text { measures } \\
\text { - Implementation } \\
\text { of the audit } \\
\text { standards }\end{array}$ & $\begin{array}{l}\text { - Review of the } \\
\text { quality control } \\
\text { system } \\
\text { - Independence } \\
\text { policies } \\
\text { regarding the } \\
\text { identification } \\
\text { of threats to } \\
\text { independence } \\
\text { - Identification } \\
\text { and application } \\
\text { of safeguards } \\
\text { in order to } \\
\text { eliminate or } \\
\text { reduce threats } \\
\text { to an acceptable } \\
\text { level }\end{array}$ & $\begin{array}{l}\text { - Employees } \\
\text { capable } \\
\text { of making } \\
\text { competent } \\
\text { managerial } \\
\text { decisions } \\
\text { - Implementation } \\
\text { of the necessary } \\
\text { policies and } \\
\text { procedures } \\
\text { for the correct } \\
\text { reporting of } \\
\text { the financial } \\
\text { statements }\end{array}$ & $\begin{array}{l}\text { - Auditor } \\
\text { management's } \\
\text { emphasis on the } \\
\text { importance of } \\
\text { independence } \\
\text { - Policies and } \\
\text { procedures for } \\
\text { implementing } \\
\text { and monitoring } \\
\text { the quality } \\
\text { of audit } \\
\text { commitments } \\
\text { - Applying } \\
\text { a disciplinary } \\
\text { mechanism } \\
\text { to promote } \\
\text { compliance with } \\
\text { audit procedures } \\
\text { and policies }\end{array}$ & $\begin{array}{l}\text { - Internal } \\
\text { procedures } \\
\text { that ensure the } \\
\text { objective setting } \\
\text { of fees for works } \\
\text { that do not } \\
\text { concern audit } \\
\text { commitments } \\
\text { - Corporate } \\
\text { governance } \\
\text { structures such } \\
\text { as an insurance } \\
\text { committee } \\
\text { that provides } \\
\text { an adequate } \\
\text { overview and } \\
\text { communications } \\
\text { regarding the } \\
\text { services offered } \\
\text { by the company }\end{array}$ \\
\hline
\end{tabular}

Source: Own projection.

\section{Conclusions}

Regardless of the factors that influence auditor independence, the appropriate judgment and ethical actions can lead to a quality audit. For this, however, an auditor must have a high level of professional knowledge and skills and assimilate the ethical behavior required by professional rules and society. Consequently, without the threat to auditor independence, there should not be any deterioration in the audit quality in the next tenure years. However, the binding effect can erode the audit quality over time, as the close personal relationship between the auditor and the client will certainly and slowly affect the auditor's judgment over time.

The developed confidence in the client activity over time adds confidence and hinders the auditor's ability to design creative and rigorous audit programs and to exercise the necessary professional skepticism.

The limitations of the research consisted of the fact that the number of analyzed articles has been reduced, as the data has been collected manually. Future research directions can materialize into the expansion of the number of articles and in the quantitative research based on collected data or even on a sample.

\section{References}

1. Ahmed, M. (2015), The Impact of Ex-Auditors' Employment with Audit Clients on Perceptions of Auditor Independence, Procedia - Social and Behavioral Sciences, Vol. 172, pp. 479-486.

2. Al-Nawaiseh, M.A.L., Alnawaiseh, M. (2015), The Effects of the Threats on the Auditor's Independence, International Business Research, Vol. 8, No. 8, pp. 141-149.

3. Alleyne, P.A., Devonish, D., Alleyne, P. (2006), Perceptions of Auditor Independence in Barbados, Managerial Auditing Journal, Vol. 21, No. 6, pp. 621-635.

4. Austin, E., Herath, S.K. (2014), Auditor Independence: A Review of Literature, International Journal of Economics and Accounting, Vol. 5, No. 1, pp. 62-74.

5. Azibi, J., Tondeur, H., Azibi, H. (2017), The Impact of the H3C on Auditor Independence in French Context, Journal of Management and Sustainability, Vol. 7, No. 2, pp. 105-115. 
6. Chang, Y.-S., Chiang, C.-Y., Liu, L.-L., Xie, X. (2019), Audit Partner Independence and Business Affiliation: Evidence from Taiwan, Advances in Accounting, Vol. 46, available at https://www.sciencedirect.com/ science/article/abs/pii/S088261101830004X, accessed at 20.11.2019.

7. Cordoş, G.S., Fulop, M.T. (2013), Auditor-Client Tenure Analysis and Its Effects on Auditor Independence, Audit Financial, No. 9, pp. 3-11.

8. DeAngelo, L.E. (1981), Auditor Size and Audit Quality, Journal of Accounting and Economics, Vol. 3, No. 3, pp. 183-199, available at https://www.sciencedirect.com/science/article/abs/pii/0165410181900021, accessed at 20.11.2019.

9. Dogui, K., Boiral, O., Gendron, Y. (2013), ISO Auditing and the Construction of Trust in Auditor Independence, Accounting, Auditing \& Accountability Journal, Vol. 26, No. 8, pp. 1279-1305.

10. Ghosh, A., Xing, C., Wang, I. (2016), Audit Quality of Complex Accounting Estimates: Evidence from Audit Tests of Goodwill and Special Charges, available at https://www.uts.edu.au/sites/default/files/Aloke\%20 Ghosh_2016\%20Summer\%20Conference.pdf, accessed at 05.11.2019.

11. Gul, F.A., Jaggi, B., Krishnan, G.V. (2007), Auditor Independence: Evidence on the Joint Effects of Auditor Tenure and Non-Audit Fees, Auditing: A Journal of Practice and Theory, available at http://ssrn.com/ abstract=984656, accessed at 05.11.2019.

12. Honigsberg, C. (2019), The Case for Individual Audit Partner Accountability, Vanderbilt Law Review, Vol. 72 , No. 26, available at https://papers.ssrn.com/sol3/papers.cfm?abstract_id=3470414, accessed at 14.11.2019.

13. Huiying, W., Ying, S.X. (2016), Realizing Auditor Independence in China: Insights from the Local Context, Contemporary Management Research, Vol. 12, No. 2, pp. 245-272.

14. Jiang, H., Habib, A., Zhou, D. (2015), Accounting Restatements and Audit Quality in China, Advances in Accounting, Vol. 31, No. 1, pp. 125-135, available at http://dx.doi.org/10.1016/j.adiac.2015.03.014, accessed at 06.11.2019.

15. Junaidi, J., Hartono, J., Suwardi, E., Miharjo, S., Hartadi, B. (2016), Does Auditor Rotation Increase Auditor Independence?, Gadjah Mada International Journal of Business, Vol. 18, No. 3, pp. 315-336.

16. Kamau, C.G., Nduati, S.K., Mutiso, A.N. (2014), Exploring Internal Auditor Independence Motivators: Kenyan Perspective, International Journal of Economics, Finance and Management Sciences, Vol. 2, No. 2, pp. $132-137$.

17. Legoria, J., Rosa, G., Soileau, J.S. (2017), Audit Quality Across Non-Audit Service Fee Benchmarks: Evidence from Material Weakness Opinions, Research in Accounting Regulation, Vol. 29, No. 2, pp. 97-108.

18. Mohamed, D.M., Habib, M.H. (2013), Auditor Independence, Audit Quality and the Mandatory Auditor Rotation in Egypt, Education, Business and Society: Contemporary Middle Eastern Issues, Vol. 6, No. 2, pp. 116-144.

19. Pittman, J., Stein, S.E., Valentine, D.F. (2020), Audit Partners' Risk Tolerance and the Impact on Audit Quality, available at https://papers.ssrn.com/sol3/papers.cfm?abstract_id=3311682, accessed at 05.05.2020.

20. Sori, Z.M., Karbhari, Y. (2017), Auditor Reputation and Auditor Independence in an Emerging Market, available at http://orca.cf.ac.uk/39372/, accessed at 03.11.2019.

21. Suseno, N.S. (2013), An Empirical Analysis of Auditor Independence and Audit Fees on Audit Quality, International Journal of Management and Business Studies, Vol. 3, No. 3, pp. 82-87.

22. Tahir, F.A., Idris, K.M.D., Ariffin, Z.Z. (2014), Dimensions of Auditor Independence: A Pilot Study, International Journal of Business and Management, Vol. 9, No. 6, pp. 72-76.

23. Tănase, G.L., Ştefănescu, A. (2020), Independence in Financial Audit Engagements. The Case of Romanian Banks, Audit Financiar, Vol. 18, No. 1(157), pp. 113-127.

24. Wu, H., Ying, S. (2016), Realizing Auditor Independence in China: Insights from the Local Context, Contemporary Management Research, Vol. 12, No. 2, pp. 245-272.

25. Yustina, A.I., Gonadi, S.A. (2019), The Negative Effect of Time Budget Pressure to Auditor Independence and Professional Skepticism, Jurnal Akuntansi dan Keuangan, Vol. 21, No. 1, pp. 38-48.

26. IFAC (2018), The International Code of Ethics for Professional Accountants: Key Areas of Focus for SMEs and SMPs, available at https://www.ifac.org/knowledge-gateway/ethics/discussion/international-code-ethicsprofessional-accountants-key-areas, accessed at 05.11.2019. 